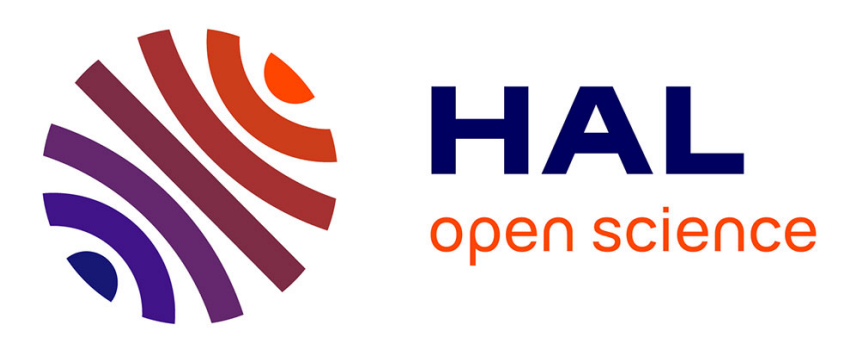

\title{
Use of Hecate-Chorionic Gonadotropin $\beta$ Conjugate in Therapy of Lutenizing Hormone Receptor Expressing Gonadal Somatic Cell Tumors
}

A. Rivero-Müller, S. Vuorenoja, M. Tuominen, A. Waclawik, L.J.S. Brokken, A.J. Ziecik, I. Huhtaniemi, N.A. Rahman

\section{To cite this version:}

A. Rivero-Müller, S. Vuorenoja, M. Tuominen, A. Waclawik, L.J.S. Brokken, et al.. Use of Hecate-Chorionic Gonadotropin $\beta$ Conjugate in Therapy of Lutenizing Hormone Receptor Expressing Gonadal Somatic Cell Tumors. Molecular and Cellular Endocrinology, 2007, 269 (1-2), pp.17. 10.1016/j.mce.2006.11.016 . hal-00531905

\section{HAL Id: hal-00531905 https://hal.science/hal-00531905}

Submitted on 4 Nov 2010

HAL is a multi-disciplinary open access archive for the deposit and dissemination of scientific research documents, whether they are published or not. The documents may come from teaching and research institutions in France or abroad, or from public or private research centers.
L'archive ouverte pluridisciplinaire HAL, est destinée au dépôt et à la diffusion de documents scientifiques de niveau recherche, publiés ou non, émanant des établissements d'enseignement et de recherche français ou étrangers, des laboratoires publics ou privés. 


\section{Accepted Manuscript}

Title: Use of Hecate-Chorionic Gonadotropin $\beta$ Conjugate in Therapy of Lutenizing Hormone Receptor Expressing Gonadal Somatic Cell Tumors

Authors: Rivero-Müller A., Vuorenoja S., Tuominen M., Wacławik A., Brokken L.J.S., Ziecik A.J., Huhtaniemi I.,

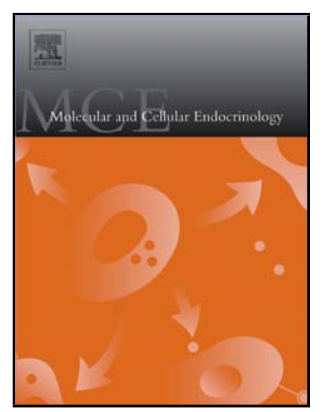
Rahman N.A.

PII:

DOI:

Reference:

S0303-7207(07)00042-1

doi:10.1016/j.mce.2006.11.016

MCE 6608

To appear in:

Molecular and Cellular Endocrinology

Received date:

$14-9-2006$

Revised date:

28-11-2006

Accepted date:

28-11-2006

Please cite this article as: Rivero-Müller, A., Vuorenoja, S., Tuominen, M., Wacławik, A., Brokken, L.J.S., Ziecik, A.J., Huhtaniemi, I., Rahman, N.A., Use of HecateChorionic Gonadotropin $\beta$ Conjugate in Therapy of Lutenizing Hormone Receptor Expressing Gonadal Somatic Cell Tumors, Molecular and Cellular Endocrinology (2007), doi:10.1016/j.mce.2006.11.016

This is a PDF file of an unedited manuscript that has been accepted for publication. As a service to our customers we are providing this early version of the manuscript. The manuscript will undergo copyediting, typesetting, and review of the resulting proof before it is published in its final form. Please note that during the production process errors may be discovered which could affect the content, and all legal disclaimers that apply to the journal pertain. 
Use of Hecate-Chorionic Gonadotropin $\beta$ Conjugate in Therapy of Lutenizing Hormone Receptor Expressing Gonadal Somatic Cell Tumors

Rivero-Müller $\mathrm{A}^{1}$, Vuorenoja $\mathrm{S}^{1}$, Tuominen $\mathrm{M}^{1}$, Wacławik $\mathrm{A}^{2}$, Brokken LJS ${ }^{1}$, Ziecik $\mathrm{AJ}^{2}$, Huhtaniemi $\mathrm{I}^{1,3}$ and Rahman $\mathrm{NA}^{1^{*}}$

${ }^{1}$ Department of Physiology, University of Turku, FIN-20520 Turku, Finland, ${ }^{2}$ Institute of Animal Reproduction and Food Research, Polish Academy of Sciences, 10-714 Olsztyn, Poland, ${ }^{3}$ Institute of Reproductive and Developmental Biology, Imperial College London, London W12 ONN, U.K.

Running title: hecate-CG $\beta$, LHR and gonadal tumors

Keywords: goanadal tumors, transgenic mice, gonadotropins, LHR, lytic peptide hecate, hecate-CG $\beta$ conjugate

Abbreviations: LHR, Luteinizing hormone receptor; hCG, human chorionic gonadotropin, hecate-CG $\beta$, Lytic peptide hecate fused to the 81-95 peptides of chorionic gonadotropin- $\beta$ (CG $\beta)$

*Correspondence: $\quad$ Nafis Rahman, M.D., Ph.D.

Department of Physiology

University of Turku

Kiinamyllynkatu 10

FIN-20520 Turku, Finland

Fax: +358-2-2502610

E-mail: nafis.rahman@utu.fi 


\begin{abstract}
Improvement of cancer treatment is a major challenge of medical research. Despite the immense efforts made in the improvement of diagnosis and treatment, cancer remains a major concern and cause of morbidity and mortality. Most of the modern anti-neoplastic therapies have severe side effects, and tumor cells often develop drug resistance. There is promise in the new generation of treatments (gene therapy, immunotherapy, vaccines, etc) that are under development, but the efficacies and side effects of such therapies have so far been disappointing. Receptor-based therapies are not new, but many normal cells also present the same receptors reducing the specificity of such approaches. Several lytic peptides have been investigated because of they appear to kill cancer cells due to changes of their membrane potential. Thus, linking receptor-specific ligands to lytic peptides is expected to augment the specificity of targeting and decrease the toxicity of lytic peptides on normal cells. One such polypeptide is hecate (an analogue to the bee venom main component, melittin) that preferentially kills cancer cells at low doses. When this peptide is fused with the 81-95 amino acid fragment of chorionic gonadotropin- $\beta$ (CG $\beta$ ) subunit (hecate-CG $\beta$ ), it targets cells expressing luteinizing hormone receptor (LHR), even at very low doses, or when LHR is expressed at low level. Our recent data showed that this peptide conjugate is efficient in destroying LHR-positive cells in xenografts and more importantly in transgenic mouse models developing LHR-positive somatic cell tumors in gonads. The mechanism of action of hecate-CG $\beta$ after binding to LHR is destruction of cell membranes resulting in rapid cell death by necrosis with minimal side effects. This review summarizes our findings on the action of this novel peptide and considers the future potential of this family of targeting peptides in the treatment of neoplasias.
\end{abstract}




\section{Introduction}

The concept of the "magic bullet", a drug or therapy that will only act on cancer cells while leaving healthy cells unharmed, has existed for more than 100 years, however, its implementation still remains a major challenge for cancer therapy. Modern chemotherapy is often limited by the severity of its side effects. The difference between the therapeutic and toxic dose is narrow, so it is critical for succesful therapy to enable the recovery of the healthy tissues before the treatment becomes too toxic. The major limitations for classical chemotherapy are that they act on all dividing cells, both malignant and normal, their effect is restricted by inherited or acquired resistance of cancer cells, and the difficulties of delivering drugs or therapies (e.g. gene therapy, selective peptide therapy) only to cancer cells and in particular to intracellular targets. In this article, we will briefly review the different aspects, modes and scopes of different direct drug delivery systems with the final emphasis on our specific drug of interest, the lytic peptide hecate-CG $\beta$.

\section{Directed therapeutic drug delivery}

In 1898, Paul Ehrlich envisioned that "bodies which possessed a particular affinity" could deliver "therapeutically active groups" to selected organs. This assumes that cancer cells have specific antigens, which could be used as targets for example to antibodies. Indeed, with the advent of monoclonal antibodies important steps in targeted therapy were made as they recognized antigens associated with many types of cancers (Kohler and Milstein 1975). Furthermore, antibody-toxin conjugates (also known as immunotoxins) and other chimeric toxins (such as epidermal growth factor [EGF] or interleukins) conjugated to various toxins were constructed as novel forms of therapy (Hertler and Frankel 1989, Pastan and FitzGerald 1991) (about eventual success of these attempts, see below).

\subsection{Toxins conjugated to antibodies, or growth factors}

Toxins conjugated to antibodies include ricin, diphtheria toxin, and Pseudomonas exotoxin, which upon delivery to specific cells induce irreversible arrest of protein synthesis (Pastan and FitzGerald 1991). Doxorubicin and other antineoplastic agents have also been linked to antibodies or growth factors to be delivered to cancer cells (Yeh et al. 1992). Moreover, several antibodies carrying 
radioactive material have been developed and are already in clinical use (e.g. Zevalin, Bexxar) (Bohdiewicz 1998). The theory behind this technology is identical to the one where antibodies conjugated with toxins, in this case radioactive isotopes, act on cells recognized by the antibody. There are major limitations of antibody-related therapy (linked to toxins, enzymes, radioactive material), for example the antibodies' poor tumor penetration due to their molecular size (Halin et al. 2002), the toxicity of nonspecific uptake of antibody in liver and reticuloendothelial system (Halpern et al. 1983, Pimm et al. 1985), and the need for tumor-specific antigens. There are few antigens specific for cancer cells a(exploited in vaccination therapy) resulting in possible toxicity to other normal cells possessing similar antigens.

\subsection{Gene therapy approach}

A newer approach is gene therapy (addition, replacement or deletion of a specific gene by introducing a foreign DNA molecule) and its new branch of siRNA targeting vectors (silencing of a specific gene). This has created great expectations for their application in cancer therapy. However, this technology requires the intracellular delivery of genetic material, usually achieved by viruses or liposomes, in order to replace, express, activate or inhibit a specific (set of) gene(s). The difficult delivery into cells, lack of cell specificity, the immune reaction and inflammation created by viral antigens, the safety risks of viral use, and the random integration of these vectors into the target cell (in the case of gene-amendment), have resulted in more problems than anticipated (Hacein-Bey-Abina et al. 2002a). As an example, a clinical trial in France where correction of X-linked severe combined immunodeficiency in 9 out of 10 patients by retrovirus-mediated gene transfer was successful (Hacein-Bey-Abina et al. 2002b), 3 years later 2 of those children developed T-cell acute leukemia (HaceinBey-Abina et al. 2003). Unfortunately, as yet there is no a safe and reliable method to integrate foreign DNA into selective areas of the genome.

\subsection{Membrane receptors as therapeutic targets}

A more efficient and selective approach would be to use membrane receptors as potential targets, which actually has been suggested for some time as an alternative to chemotherapy. Indeed, the discovery of the death-inducing receptors (TNF, Fas, TRAIL) was brought to particular attention, but their therapeutic use has unfortunately been suspended due to drastic side effects towards the liver cells 
(Kakinuma et al. 1999, Lawrence et al. 2001), among others, and the resistance of some cancer cells to the apoptotic pathway induced by these receptors (Timmer et al. 2002). One major advantage of membrane receptors is that there is no need of intracellular delivery for cell selection, as the receptor is exposed to the extracellular environment. Membrane receptors usually have high specific affinity to the targeting ligands. Thus mimicking the receptor's natural ligand structure in a fusion peptide with the toxin would result in highly specific targeting. Genetically modifying viral vectors to bind and deliver their genetic contents into specific cell types has been reported (Kasahara et al. 1994, Yoon et al. 2001). However, this modification of gene therapy is still in its early stage, as the low integration rates especially in non-dividing cells together with their random integration into the genome have the potential of resulting in other genetically unwanted modifications.

\subsection{Cationic peptides}

Recently, attention has been directed to a particular group of cationic peptides as an alternative therapy for cancer. Cationic lytic peptides play an important role in the innate immunity of multicellular organisms (Boman 1995, Zasloff 2002). They serve as defense molecules against microorganisms (bacteria, fungi and viruses) especially in insects that do not possess an immune system (lymphocytes or antibodies). Despite the diversity of these peptides, they share common characteristics: positive charge, linearity, amphipathic and $\alpha$-helical structure in a hydrophobic environment and rapid destruction of negatively charged membranes (Leuschner and Hansel 2004) (Figure 1). Most of these peptides are toxic to bacteria but elude normal eukaryotic cells. This is because of clear fundamental differences in their membrane composition. Bacterial membranes are heavily populated with negatively charged phospholipid headgroups while the animal and plant cell membranes (mainly zwitterionic phospholipids, phosphatydylcholine, cholesterol, sphingomyelin, phosphatidylethanolamine) on the outer leaflet [for a review, see (Matsuzaki 1999)] have no net charge. Cancer cells also have a different membrane composition, containing 3-7 times more phosphatidylserine (PS) (normally located only in the inner leaflet of the membrane) resulting in negative charged outer membrane (Utsugi et al. 1991) making them more susceptible to the lytic activity of cationic peptides. 


\subsubsection{Cationic lytic peptides melittin and hecate}

Some lytic peptides bind and act on both types of membranes (negatively and positively charged), including the main component of the honeybee (Apis mellifera) venom melittin, the neurotoxin pardaxin from Mosses sole fish, and amoebapore isolated from Entamoeba histolytica [for a review, see (Leuschner and Hansel 2004)]. However some changes in their structure may increase their specific activity against negatively charged membranes. Hecate, an analogue of melittin, was designed to retain the $\alpha$-helical structure with altered charge distribution. As a result of these changes this peptide destroys bacterial cells (Henk et al. 1995) but has limited haemolytic properties (21\%), and for example does not destroy African green monkey cells at low concentrations. In contrast, hecate was shown to be toxic towards a number of cancer cell lines (breast, ovarian and prostate) at low concentrations (2$12 \mu \mathrm{M}$ ) (Leuschner et al. 2001, Leuschner et al. 2003b).

\subsubsection{Lytic peptide hecate conjugated to CG $\beta$ (hecate-CG $\beta$ )}

Hecate-conjugate is a fusion polypeptide of the 23-amino acid hecate tethered with a 15 amino acid (81-95) fragment of the CG $\beta$ subunit responsible for luteinizing hormone receptor (LHR) binding (Morbeck et al. 1993). This polypeptide directly targets LHR expressing cells and the therapeutic efficacy has been shown to be dependent on the number of LHR in target cells (Gawronska et al. 2002). Hence, cells expressing more LHR molecules are more likely to be killed by this drug. Moreover, hecate-CG $\beta$, as many other cationic peptides, has per se a high specific affinity for prokaryotic and cancer cells but very low affinity for normal cells. This has been attributed to the similar membrane potential of prokaryotic and cancer cells which differs from normal eukaryotic cells [Figure 1, modified from (Shai 1999) and (Matsuzaki 1999)].

In vitro, lytic peptides are shown to be highly specific for cancer cells with relatively low toxicity for normal cells (Papo and Shai 2003). They are usually small molecules and can easily penetrate solid tumor tissues. The limitation of lytic peptides as in vivo therapeutics is their quick inactivation in serum before reaching the target (Peck-Miller et al. 1993, Oren et al. 1997). Hecate has also demonstrated higher affinity for cancer cells in in vitro tests, but no effect on tumor cells could be found in 
vivo (Leuschner and Hansel 2004, Bodek et al. 2005), which could be due to its low stability in serum. Hecate-CG $\beta$ instead has been reported to be specific in vitro and in vivo for cells expressing LHR, making this drug feasible for therapy of tumors expressing such receptors. Hecate-CG $\beta$ has specific affinity for the LHR, as it competes with $\mathrm{LH} / \mathrm{hCG}$ for receptor binding and blocks the receptor when binding to it (Hansel et al. 2001, Leuschner et al. 2001). Hypothetically, it is possible that hecate-CG $\beta$ becomes more stable upon binding to the LHR, exposing the hecate molecule in a close proximity to the cell membrane. Cancer cell membranes possess high membrane potential, thus the hecate $\alpha$-helix binds and disrupts the adjacent membrane (Figure 2). In rat mammary gland tumors induced by combined prenatalexposure to synthetic estrogen ditehylstilbestrol (DES) and additional postnatalexposure to 7,12-dimethylbenz(a)anthracene (DMBA), we showed that targeted ablation of mammary gland tumors by hecate-CG $\beta$ conjugate is possible, even in tumor tissues that have very low or below the detectable levels of LHR expression (Zaleska et al. 2003). These findings emphasize the need for further exploration of the in vivo mechanisms of action of the hecate-CG $\beta$ conjugate in mammary tumors and the putative systemic effects induced by this treatment which may have affected the treatment outcome.

\subsubsection{Hormonal receptors (i.e. LHR) as specific targets for hecate}

Hormonal receptors such as the LHR, follicle-stimulating hormone receptor (FSHR), and thyroid-stimulating hormone receptor (TSHR), are characterized by a large N-terminal extracellular domain with high-affinity binding of their cognate glycoprotein hormone. This high affinity and specificity of hormone binding and the selective expression of the receptors in specific cells make them perfect candidates for the delivery of receptor-directed drugs. LHR plays an essential role in reproductive physiology of males and females and is mainly expressed in gonadal somatic cells. In testes, it is expressed in Leydig cells, and in the ovary, the expression occurs in theca, interstitial, differentiated granulosa and luteal cells. The main physiological roles of LHR are confined to its actions in the testes and ovaries. Therefore, gonadal somatic cell tumors (granulosa and Leydig cell) express high levels of LHR. Under therapeutic circumstances the main expected therapeutic effects of hecateCG $\beta$ conjugate would be to destroy these LHR expressing cells with very mild or 
absent collateral damage outside the target cells compared to any modern anticancer drugs. Moreover, animal experiments carrying cancer cell xenografts, where hecateCG $\beta$ or Phor21/CG $\beta$ (ala) were used for treatment, showed minor to no side effects on gonadal tissues at low doses (Hansel et al. 2001). This is the result of the preferential action of cationic lytic peptides for cancer cells membranes. In the case of gonadal tumors (specifically normally LHR-positive cells after malignant transformation, see below) hecate-CG $\beta$ treatment results in total ablation of these cells from the tissue without detectable side effects in vital organs (Bodek et al. 2005).

\subsubsection{Gonadal somatic cell tumors and LHR}

Gonadal somatic cell tumors are relatively rare but as their diagnosis and treatment are difficult, they form a particularly fatal group of malignancies. Testicular tumors are the most common malignancy in men between 15-34 years of age (Kinkade 1999), even if such tumors account only for $1 \%$ of all tumors in males. Leydig cell tumors are generally benign and account for about $2 \%$ of all testicular tumors, with malignancy occurring in about $10 \%$ of the cases (Kinkade 1999). Ovarian carcinomas are difficult to detect, and usually they are only detected at the late stages (II or IV) due to a lack of diagnostic tests and clear symptoms, and are often called the "silent killer" (Crayford et al. 2000, Goff et al. 2000). Among the ovarian tumors, those of granulosa cell origin are rare, $3.0 \%-7.6 \%$ of primary ovarian tumors, but the life expectancy after treatment is short in comparison to other ovarian cancers (Cronje et al. 1999, Crayford et al. 2000), the tumor-related mortality rate is $37.3 \%$ (Cronje et al. 1999), and approximately $80 \%$ of patients die of recurrent disease (Young et al. 1984, Cronje et al. 1999). The majority of human ovarian cancers are ovarian surface epithelial tumors, and $70 \%$ of them are shown to express LHR (Mandai et al. 1997, Konishi et al. 1999, Lu et al. 2000, Auersperg et al. 2001, Kuroda et al. 2001).

\subsubsection{In vivo trials of hecate-CG $\beta$ conjugate}

In vivo testing of hecate-CG $\beta$ has shown promising results on cancer cell xenografts (Hansel et al. 2001, Leuschner et al. 2001, Gawronska et al. 2002, Leuschner et al. 2003a, Leuschner et al. 2003b). Xenograft tumors are generally established by the subcutaneous inoculation of tumor cells into athymic nude mice. 
Growth of solid tumors is monitored using in situ caliper measurements. In most cases, drug activity is defined by the delay in tumor growth, or net number of cells killed. Drug-related deaths and body weight loss are used as parameters of toxicity. However, many agents with promising activity in xenograft models produced disappointing results when subjected to clinical phase studies [for a review, see (Sharpless and Depinho 2006)]. Thus, there has been considerable controversy regarding the value of xenograft models (Suggitt and Bibby 2005). Often xenograft models contain monoclonal cells, which in many cases are chemoresistant or chemosensitive as their environment is depleted, for example of hormones and growth factors. In order to study tumor progression and development in vivo and to monitor the methods of treatment, and their overall efficacy, there is a need of animal models that develop somatic cell tumors.

In comparison to xenograft-models, animal tumor models provide an opportunity for precise investigation of molecular, genetic, hormonal and cellular changes of neoplastic transformation at different stages. In addition they serve as experimental models resembling human diseases for prevention, diagnostic screening and treatment (Vanderhyden et al. 2003). This is because tumor formation is more physiological/pathophysiological as the cancer cells develop directly in the environment where the tumor is expected or would normally arise in humans.

In our laboratory, we have developed a transgenic murine model that expresses the SV40 T antigen proteins under the inhibin- $\alpha$ promoter (Inh $\alpha / \mathrm{Tag}$ ) (Kananen et al. 1995). These mice develop malignant Leydig and granulosa cell tumors (both expressing LHRs) with $100 \%$ penetrance at the age of 5 months (Kananen et al. 1995, Kananen et al. 1996). Tumor cell lines immortalized from these tumors (Leydig and granulosa) produced high levels of progesterone, and the resulting high serum level of progesterone and reduced gonadotropins (Kananen et al. 1996, Rahman and Huhtaniemi 2001) were used as a markers of endocrine consequences of the treatment. We hypothesized that hecate-CG $\beta$ conjugate should suppress tumorigenesis by killing the LHR expressing tumor cells in this in vivo transgenic mouse model. Indeed, hecate-CG $\beta$ conjugate treatment reduced the testicular and ovarian tumor burden (tumor volume/body weight) significantly, whereas during hecate treatment there was a significant concomitant increase in testicular, but no change in ovarian volumes. Figure 3 shows a representative image 
of testicular tumor before and after hecate-CG $\beta$ conjugate treatment. In addition, there was a drop in serum progesterone, produced by the tumors, and increase in LH levels in hecate-CG $\beta$ conjugate treated mice, in comparison with TG control and hecate treated groups, highlighting the positive treatment results (Bodek et al. 2005). In female Inh $\alpha /$ Tag mice treated with hecate-CG $\beta$, the therapeutic effect was less pronounced than in treated males (Bodek et al. 2005). This could have been the result of higher circulating LH levels in female animals, which compete with the injected drug, or of a smaller number of LHR in granulosa cell than in Leydig cell tumors. Reduction of circulating serum LH levels, e.g. by GnRH agonist or antagonist pretreatment, or by increasing the number of LHRs in the tumor e.g. by pre-treatment with estradiol (Gawronska et al. 1999), could enhance the treatment outcome in granulosa cell tumors.

\subsubsection{Molecular mechanisms underlying hecate-CG $\beta$ mode of cell death}

As many pathways were discovered in the last 30 years for programmed cell death or apoptosis, it looked an obvious therapeutic approach (see above, death receptors) for inducing cell specific deletion. Apoptosis is initiated by a plethora of stimuli, which finally converge on a common effector's cell-dismantlement process mediated by caspases. This process is balanced by inhibitors and antagonists (inhibitors of Apoptosis (IAPs), survivin, BcL-2, FLIP), which often are overexpressed in cancer cells (Jaattela 1999, Chawla-Sarkar et al. 2004, Nomura et al. 2005). An increasing number of reports on cancer cell escape or block of apoptosis has undermined the therapeutic applicability of apoptosis. We have recently found that hecate-CG $\beta$ conjugate induced a rapid and cell-specific membrane permeabilization of LHR expressing cells in vitro, suggesting a necrotic mode of cell death, without activation of apoptosis (Bodek et al. 2005), as determined by flow cytometry, caspase- 3 activation, and by the pan-caspase inhibitor Z-VAD treatment (Figures 4 and 5). Lytic hecate-CG $\beta$ peptide action, in contrast to other therapies, seems to act by perforating the cell membrane, resulting in swelling and bursting, in other words by inducing necrosis or necrosis-like cell death. The induction of a combination between apoptosis and necrosis or necrosis alone could be a beneficial therapeutic outcome (Los et al. 2002, Burek et al. 2003, Los et al. 2003, Lin et al. 2004, Rosal et al. 2005) to overcome multiple drug resistance. 
As an example, where targeted-necrosis is induced, vascular targeting agents (VTAs) specifically target pre-existing blood vessels of tumors causing rapid necrosis by vascular shutdown. This mode of action allows VTAs to kill tumor cells resistant to conventional chemotherapy and radiotherapy as well as destruction of the tumor core, which are usually hypoxic (Gaya and Rustin 2005). However, its action is limited in tumor metastases and non-solid tumors, so while targeting the integrity of the cancer cell membrane is a rapid and destructive process, the treatment also acts at the single cell basis (Papo et al. 2003). Several lytic peptides have been reported per se to have preference for cancer cell membranes (see above), however their stability and efficacy in vivo still remain unknown (Papo et al. 2003). These peptides linked to a ligand for a specific receptor (such as the hecate-CG $\beta$ conjugate) increase the specificity, reduced toxicity and improved their anti-neoplastic activity.

\section{Conclusions and future goals}

The more we know about this novel drug, the clearer it seems that lyticpeptides delivered to membrane receptors have a potential of a drug for targeted therapy, which might overcome many of the limitations of current therapies. Also the better we understand the function of these drugs and the potential receptors that could be used as their targets, the better are our chances to modify them to specifically kill tumor cells. The mode of action of lytic peptides, disruption of charged-cell membrane, and thus necrosis or necrosis-like cell death, raises a new possibility for the treatment of apoptosis- and multi-drug-resistant tumors, which otherwise would not be killed by conventional therapy. What at first glance seemed like a disappointing finding, the non-apoptotic mode of cell death (Bodek et al. 2005), may after all be a beneficial effect. The single cell action of lytic-targeted peptides is a major advantage in tumor metastases and non-dividing tumors (e.g. early stages). The minimal side effects, resulting from the high specificity of the hormone peptide for their receptors and the preference for cells with altered membrane potential, suggest that many other receptors can be used as targets in cancer cells. Clinical studies of hecate-CG $\beta$ and Phor21/CG $\beta$ (ala) will soon provide us with more evidence on their uses and limitations in human LHR expressing endocrine cancer therapy. As several of the human endocrine cancer tissues, such as mammary gland (Meduri et al. 1997), prostate (Tao et al. 1997), and adrenal cortical tumor (Rao et al. 2004) express LHR, 
hecate- $\beta C G$ conjugate could be highly effective in treating other types of human cancers through their LHR, at least as adjuvant therapy. Of course follow-up studies and tumor recurrence after hecate- $\beta C G$ treatments, and other lytic complexes, should be priority research areas in the future. 
Figure legends

Figure 1. Characteristics of lytic peptides.

Lytic peptides are positively charged, linear, amphipathic and $\alpha$-helical in a hydrophobic environment, and are able to destroy rapidly negatively charged membranes (bacteria or cancer cells) with much less effect on positively charged membranes (normal somatic/eukaryotic cells).

Figure 2. Hecate-CG $\beta$ conjugate structure and mode of action.

Hecate-CG $\beta$ conjugate is a fusion polypeptide conformed of 23 amino acids of hecate and the 15 amino acids of the chorionic gonadotropin $\beta$ (CG $\beta$ ) chain responsible for luteinizing hormone receptor (LHR) high affinity binding. Thus it binds to the LHR (a) and becomes more stable, exposing the hecate $\alpha$-helix molecule in a close proximity of the cell membrane (b). Cancer cell membranes possess high membrane potential which helps the hecate $\alpha$-helix to bind and disrupt the adjacent membrane (c).

Figure 3. Testicular tumor before and after hecate-CG $\beta$ treatment.

A representative image of testicular tumors (both) in inh $\alpha /$ Tag TG mice connected with adhesions "before" (during the longitudinal laparotopy) (left panel), and the same tumors "after" hecate-CG $\beta$ conjugate treatment (right panel).

Figure 4. Flow-cytometric analysis of murine Leydig tumor BLT-1 nuclei as a marker for apoptosis.

Murine Leydig tumor BLT-1 cells were treated for $4 \mathrm{~h}$ with $1 \mu \mathrm{M}$ of hecate-CG $\beta$ conjugate or hecate. Cells treated with $0.1 \% \mathrm{H}_{2} \mathrm{O}_{2}$ were used as positive apoptotic controls. Percentage of cells undergoing apoptosis by nuclear fragmentation was analyzed by flow cytometry. The number of fragmented nuclei (top left quadrant) represents the percentage of apoptotic cells (marked as \% on each case). Neither hecate-CG $\beta$ conjugate nor hecate treatment induced nuclear fragmentation in BLT-1 cells but cells were dead as determined by a cell viability test (see next figure).

Figure 5. Inhibition of apoptosis does not protect from hecate-CG $\beta$ action. 
Cells were pre-treated with pan-caspase inhibitor Z-VAD (Calbiochem) and incubated for $1 \mathrm{~h}$ before treatment with hecate or hecate-CG $\beta$ conjugate at different concentrations. Cells were then incubated overnight. $0.1 \% \mathrm{H}_{2} \mathrm{O}_{2}$ was used as the positive control for apoptosis. A colorimetric MTT assay was then performed to measure cell survival. Viability in the treated cells was expressed as percentage of controls. The untreated controls were assigned a value of $100 \%$. Presence or absence of Z-VAD did not significantly change BLT-1 and mLTC-1 cells viability after treatment of the hecate-CG $\beta$ conjugate, while in the positive control for apoptosis the presence of Z-VAD was able to block apoptosis significantly (50\%). These results further proved that the mode of cell death caused by the hecate or hecate-CG $\beta$ conjugate was not apoptosis. 


\section{RERENCES}

Auersperg, N., Wong, A.S., Choi, K.C., Kang, S.K. and Leung, P.C., 2001. Ovarian surface epithelium: biology, endocrinology, and pathology. Endocr Rev 22, 255-88.

Bodek, G., Vierre, S., Rivero-Muller, A., Huhtaniemi, I., Ziecik, A.J. and Rahman, N.A., 2005. A novel targeted therapy of Leydig and granulosa cell tumors through the luteinizing hormone receptor using a hecate-chorionic gonadotropin beta conjugate in transgenic mice. Neoplasia 7, 497-508.

Bohdiewicz, P.J., 1998. Indium-111 satumomab pendetide: the first FDA-approved monoclonal antibody for tumor imaging. J Nucl Med Technol 26, 155-63; quiz 170-1.

Boman, H.G., 1995. Peptide antibiotics and their role in innate immunity. Annu Rev Immunol 13, 61-92.

Burek, C., Burek, M., Roth, J. and Los, M., 2003. Calcium induces apoptosis and necrosis in hematopoetic malignant cells:Evidence of caspase- 8 dependent and FADD-autonomous pathway. Gene Ther Mol Biol, 173-179.

Chawla-Sarkar, M., Bae, S.I., Reu, F.J., Jacobs, B.S., Lindner, D.J. and Borden, E.C., 2004. Downregulation of Bcl-2, FLIP or IAPs (XIAP and survivin) by siRNAs sensitizes resistant melanoma cells to Apo2L/TRAIL-induced apoptosis. Cell Death Differ 11, 915-23.

Crayford, T.J., Campbell, S., Bourne, T.H., Rawson, H.J. and Collins, W.P., 2000. Benign ovarian cysts and ovarian cancer: a cohort study with implications for screening. Lancet 355, 1060-3.

Cronje, H.S., Niemand, I., Bam, R.H. and Woodruff, J.D., 1999. Review of the granulosa-theca cell tumors from the emil Novak ovarian tumor registry. Am J Obstet Gynecol 180, 323-7.

Gawronska, B., Leuschner, C., Enright, F.M. and Hansel, W., 2002. Effects of a lytic peptide conjugated to beta HCG on ovarian cancer: studies in vitro and in vivo. Gynecol Oncol 85, 45-52.

Gawronska, B., Paukku, T., Huhtaniemi, I., Wasowicz, G. and Ziecik, A.J., 1999. Oestrogen-dependent expression of $\mathrm{LH} / \mathrm{hCG}$ receptors in pig Fallopian tube and their role in relaxation of the oviduct. J Reprod Fertil 115, 293-301.

Gaya, A.M. and Rustin, G.J., 2005. Vascular disrupting agents: a new class of drug in cancer therapy. Clin Oncol (R Coll Radiol) 17, 277-90.

Goff, B.A., Mandel, L., Muntz, H.G. and Melancon, C.H., 2000. Ovarian carcinoma diagnosis. Cancer 89, 2068-75.

Hacein-Bey-Abina, S., Fischer, A. and Cavazzana-Calvo, M., 2002a. Gene therapy of X-linked severe combined immunodeficiency. Int J Hematol 76, 295-8.

Hacein-Bey-Abina, S., Le Deist, F., Carlier, F., Bouneaud, C., Hue, C., De Villartay, J.P., Thrasher, A.J., Wulffraat, N., Sorensen, R., Dupuis-Girod, S., Fischer, A., Davies, E.G., Kuis, W., Leiva, L. and Cavazzana-Calvo, M., 2002b. Sustained correction of X-linked severe combined immunodeficiency by ex vivo gene therapy. N Engl J Med 346, 1185-93.

Hacein-Bey-Abina, S., Von Kalle, C., Schmidt, M., McCormack, M.P., Wulffraat, N., Leboulch, P., Lim, A., Osborne, C.S., Pawliuk, R., Morillon, E., Sorensen, R., Forster, A., Fraser, P., Cohen, J.I., de Saint Basile, G., Alexander, I., Wintergerst, U., Frebourg, T., Aurias, A., Stoppa-Lyonnet, D., Romana, S., Radford-Weiss, I., Gross, F., Valensi, F., Delabesse, E., Macintyre, E., Sigaux, F., Soulier, J., Leiva, L.E., Wissler, M., Prinz, C., Rabbitts, T.H., Le Deist, F., Fischer, A. and Cavazzana-Calvo, M., 2003. LMO2-associated clonal T cell 
proliferation in two patients after gene therapy for SCID-X1. Science 302, 415-9.

Halin, C., Niesner, U., Villani, M.E., Zardi, L. and Neri, D., 2002. Tumor-targeting properties of antibody-vascular endothelial growth factor fusion proteins. Int $\mathbf{J}$ Cancer 102, 109-16.

Halpern, S.E., Hagan, P.L., Garver, P.R., Koziol, J.A., Chen, A.W., Frincke, J.M., Bartholomew, R.M., David, G.S. and Adams, T.H., 1983. Stability, characterization, and kinetics of 111In-labeled monoclonal antitumor antibodies in normal animals and nude mouse-human tumor models. Cancer Res 43, 5347-55.

Hansel, W., Leuschner, C., Gawronska, B. and Enright, F., 2001. Targeted destruction of prostate cancer cells and xenografts by lytic peptide-betaLH conjugates. Reprod Biol 1, 20-32.

Henk, W.G., Todd, W.J., Enright, F.M. and Mitchell, P.S., 1995. The morphological effects of two antimicrobial peptides, hecate-1 and melittin, on Escherichia coli. Scanning Microsc 9, 501-7.

Hertler, A.A. and Frankel, A.E., 1989. Immunotoxins: a clinical review of their use in the treatment of malignancies. J Clin Oncol 7, 1932-42.

Jaattela, M., 1999. Escaping cell death: survival proteins in cancer. Exp Cell Res 248, 30-43.

Kakinuma, C., Takagaki, K., Yatomi, T., Nakamura, N., Nagata, S., Uemura, A. and Shibutani, Y., 1999. Acute toxicity of an anti-Fas antibody in mice. Toxicol Pathol 27, 412-20.

Kananen, K., Markkula, M., El-Hefnawy, T., Zhang, F.P., Paukku, T., Su, J.G., Hsueh, A.J. and Huhtaniemi, I., 1996. The mouse inhibin alpha-subunit promoter directs SV40 T-antigen to Leydig cells in transgenic mice. Mol Cell Endocrinol 119, 135-46.

Kananen, K., Markkula, M., Rainio, E., Su, J.G., Hsueh, A.J. and Huhtaniemi, I.T., 1995. Gonadal tumorigenesis in transgenic mice bearing the mouse inhibin alpha-subunit promoter/simian virus T-antigen fusion gene: characterization of ovarian tumors and establishment of gonadotropin- responsive granulosa cell lines. Mol Endocrinol 9, 616-27.

Kasahara, N., Dozy, A.M. and Kan, Y.W., 1994. Tissue-specific targeting of retroviral vectors through ligand-receptor interactions. Science 266, 1373-6.

Kinkade, S., 1999. Testicular cancer. Am Fam Physician 59, 2539-44, 2549-50.

Kohler, G. and Milstein, C., 1975. Continuous cultures of fused cells secreting antibody of predefined specificity. Nature 256, 495-7.

Konishi, I., Kuroda, H. and Mandai, M., 1999. Review: gonadotropins and development of ovarian cancer. Oncology 57 Suppl 2, 45-8.

Kuroda, H., Mandai, M., Konishi, I., Tsuruta, Y., Kusakari, T., Kariya, M. and Fujii, S., 2001. Human ovarian surface epithelial (OSE) cells express LH/hCG receptors, and hCG inhibits apoptosis of OSE cells via up-regulation of insulin-like growth factor-1. Int J Cancer 91, 309-15.

Lawrence, D., Shahrokh, Z., Marsters, S., Achilles, K., Shih, D., Mounho, B., Hillan, K., Totpal, K., DeForge, L., Schow, P., Hooley, J., Sherwood, S., Pai, R., Leung, S., Khan, L., Gliniak, B., Bussiere, J., Smith, C.A., Strom, S.S., Kelley, S., Fox, J.A., Thomas, D. and Ashkenazi, A., 2001. Differential hepatocyte toxicity of recombinant Apo2L/TRAIL versions. Nat Med 7, 3835 . 
Leuschner, C., Enright, F.M., Gawronska-Kozak, B. and Hansel, W., 2003a. Human prostate cancer cells and xenografts are targeted and destroyed through luteinizing hormone releasing hormone receptors. Prostate 56, 239-49.

Leuschner, C., Enright, F.M., Gawronska, B. and Hansel, W., 2003b. Membrane disrupting lytic peptide conjugates destroy hormone dependent and independent breast cancer cells in vitro and in vivo. Breast Cancer Res Treat 78, 17-27.

Leuschner, C., Enright, F.M., Melrose, P.A. and Hansel, W., 2001. Targeted destruction of androgen-sensitive and -insensitive prostate cancer cells and xenografts through luteinizing hormone receptors. Prostate 46, 116-25.

Leuschner, C. and Hansel, W., 2004. Membrane disrupting lytic peptides for cancer treatments. Curr Pharm Des 10, 2299-310.

Lin, Y., Choksi, S., Shen, H.M., Yang, Q.F., Hur, G.M., Kim, Y.S., Tran, J.H., Nedospasov, S.A. and Liu, Z.G., 2004. Tumor necrosis factor-induced nonapoptotic cell death requires receptor-interacting protein-mediated cellular reactive oxygen species accumulation. J Biol Chem 279, 10822-8.

Los, M., Burek, C.J., Stroh, C., Benedyk, K., Hug, H. and Mackiewicz, A., 2003. Anticancer drugs of tomorrow: apoptotic pathways as targets for drug design. Drug Discov Today 8, 67-77.

Los, M., Mozoluk, M., Ferrari, D., Stepczynska, A., Stroh, C., Renz, A., Herceg, Z., Wang, Z.Q. and Schulze-Osthoff, K., 2002. Activation and caspase-mediated inhibition of PARP: a molecular switch between fibroblast necrosis and apoptosis in death receptor signaling. Mol Biol Cell 13, 978-88.

Lu, J.J., Zheng, Y., Kang, X., Yuan, J.M., Lauchlan, S.C., Pike, M.C. and Zheng, W., 2000. Decreased luteinizing hormone receptor mRNA expression in human ovarian epithelial cancer. Gynecol Oncol 79, 158-68.

Mandai, M., Konishi, I., Kuroda, H., Fukumoto, M., Komatsu, T., Yamamoto, S., Nanbu, K., Rao, C.V. and Mori, T., 1997. Messenger ribonucleic acid expression of $\mathrm{LH} / \mathrm{hCG}$ receptor gene in human ovarian carcinomas. Eur $\mathbf{J}$ Cancer 33, 1501-7.

Matsuzaki, K., 1999. Why and how are peptide-lipid interactions utilized for selfdefense? Magainins and tachyplesins as archetypes. Biochim Biophys Acta 1462, 1-10.

Meduri, G., Charnaux, N., Loosfelt, H., Jolivet, A., Spyratos, F., Brailly, S. and Milgrom, E., 1997. Luteinizing hormone/human chorionic gonadotropin receptors in breast cancer. Cancer Res 57, 857-64.

Morbeck, D.E., Roche, P.C., Keutmann, H.T. and McCormick, D.J., 1993. A receptor binding site identified in the region $81-95$ of the beta- subunit of human luteinizing hormone (LH) and chorionic gonadotropin (hCG). Mol Cell Endocrinol 97, 173-81.

Nomura, T., Yamasaki, M., Nomura, Y. and Mimata, H., 2005. Expression of the inhibitors of apoptosis proteins in cisplatin-resistant prostate cancer cells. Oncol Rep 14, 993-7.

Oren, Z., Hong, J. and Shai, Y., 1997. A repertoire of novel antibacterial diastereomeric peptides with selective cytolytic activity. J Biol Chem 272, 14643-9.

Papo, N., Shahar, M., Eisenbach, L. and Shai, Y., 2003. A novel lytic peptide composed of DL-amino acids selectively kills cancer cells in culture and in mice. J Biol Chem 278, 21018-23. 
Papo, N. and Shai, Y., 2003. New lytic peptides based on the D,L-amphipathic helix motif preferentially kill tumor cells compared to normal cells. Biochemistry 42, 9346-54.

Pastan, I. and FitzGerald, D., 1991. Recombinant toxins for cancer treatment. Science 254, 1173-7.

Peck-Miller, K.A., Darveau, R.P. and Fell, H.P., 1993. Identification of serum components that inhibit the tumoricidal activity of amphiphilic alpha helical peptides. Cancer Chemother Pharmacol 32, 109-15.

Pimm, M.V., Perkins, A.C. and Baldwin, R.W., 1985. Differences in tumour and normal tissue concentrations of iodine- and indium-labelled monoclonal antibody. II. Biodistribution studies in mice with human tumour xenografts. Eur J Nucl Med 11, 300-4.

Rahman, N.A. and Huhtaniemi, I.T., 2001. Ovarian tumorigenesis in mice transgenic for murine inhibin alpha subunit promoter-driven Simian Virus $40 \mathrm{~T}$-antigen: ontogeny, functional characteristics, and endocrine effects. Biol Reprod 64, 1122-30.

Rao Ch, V., Zhou, X.L. and Lei, Z.M., 2004. Functional luteinizing hormone/chorionic gonadotropin receptors in human adrenal cortical H295R cells. Biol Reprod 71, 579-87.

Rosal, R., Brandt-Rauf, P., Pincus, M.R., Wang, H., Mao, Y., Li, Y. and Fine, R.L., 2005. The role of alpha-helical structure in p53 peptides as a determinant for their mechanism of cell death: necrosis versus apoptosis. Adv Drug Deliv Rev 57, 653-60.

Shai, Y., 1999. Mechanism of the binding, insertion and destabilization of phospholipid bilayer membranes by alpha-helical antimicrobial and cell nonselective membrane-lytic peptides. Biochim Biophys Acta 1462, 55-70.

Sharpless, N.E. and Depinho, R.A., 2006. The mighty mouse: genetically engineered mouse models in cancer drug development. Nat Rev Drug Discov 5, 741-54.

Suggitt, M. and Bibby, M.C., 2005. 50 years of preclinical anticancer drug screening: empirical to target-driven approaches. Clin Cancer Res 11, 971-81.

Tao, Y.X., Bao, S., Ackermann, D.M., Lei, Z.M. and Rao, C.V., 1997. Expression of luteinizing hormone/human chorionic gonadotropin receptor gene in benign prostatic hyperplasia and in prostate carcinoma in humans. Biol Reprod 56, 67-72.

Timmer, T., de Vries, E.G. and de Jong, S., 2002. Fas receptor-mediated apoptosis: a clinical application? J Pathol 196, 125-34.

Utsugi, T., Schroit, A.J., Connor, J., Bucana, C.D. and Fidler, I.J., 1991. Elevated expression of phosphatidylserine in the outer membrane leaflet of human tumor cells and recognition by activated human blood monocytes. Cancer Res 51, 3062-6.

Vanderhyden, B.C., Shaw, T.J. and Ethier, J.F., 2003. Animal models of ovarian cancer. Reprod Biol Endocrinol 1, 67.

Yeh, M.Y., Roffler, S.R. and Yu, M.H., 1992. Doxorubicin: monoclonal antibody conjugate for therapy of human cervical carcinoma. Int J Cancer 51, 274-82.

Yoon, T.K., Shichinohe, T., Laquerre, S. and Kasahara, N., 2001. Selectively replicating adenoviruses for oncolytic therapy. Curr Cancer Drug Targets 1, 85-107.

Young, R.H., Dickersin, G.R. and Scully, R.E., 1984. Juvenile granulosa cell tumor of the ovary. A clinicopathological analysis of 125 cases. Am J Surg Pathol 8, 575-96. 
Zaleska, M., Bodek, G., Jana, B., Hansel, W. and Ziecik, A.J., 2003. Targeted Destruction of Normal and Cancer Cells Through Lutropin/Choriogonadotropin Receptors Using Hecate-betaCG Conjugate. Exp Clin Endocrinol Diabetes 111, 146-53.

Zasloff, M., 2002. Antimicrobial peptides of multicellular organisms. Nature 415, 389-95. 


\section{Outside}

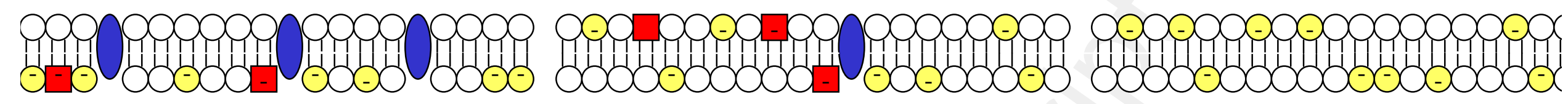

Plasma membrane of multicellular animal

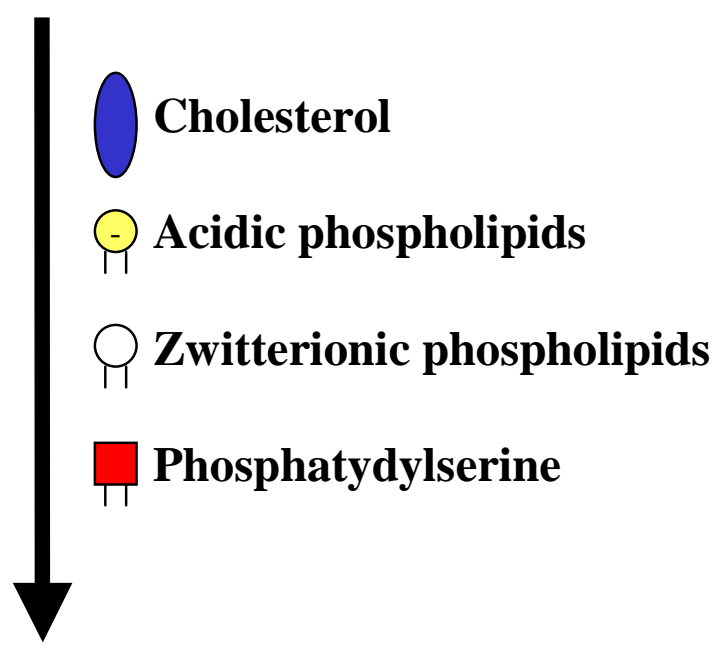

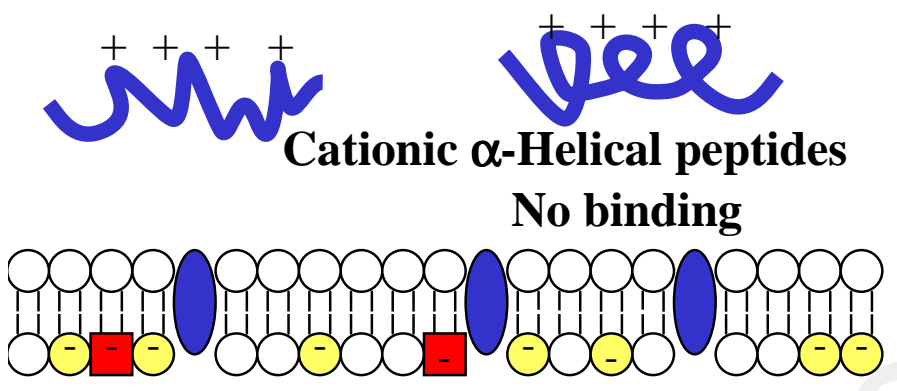

Fig. 1
Cancer cell plasma membrane

\section{Bacterial cytoplasmic membrane}
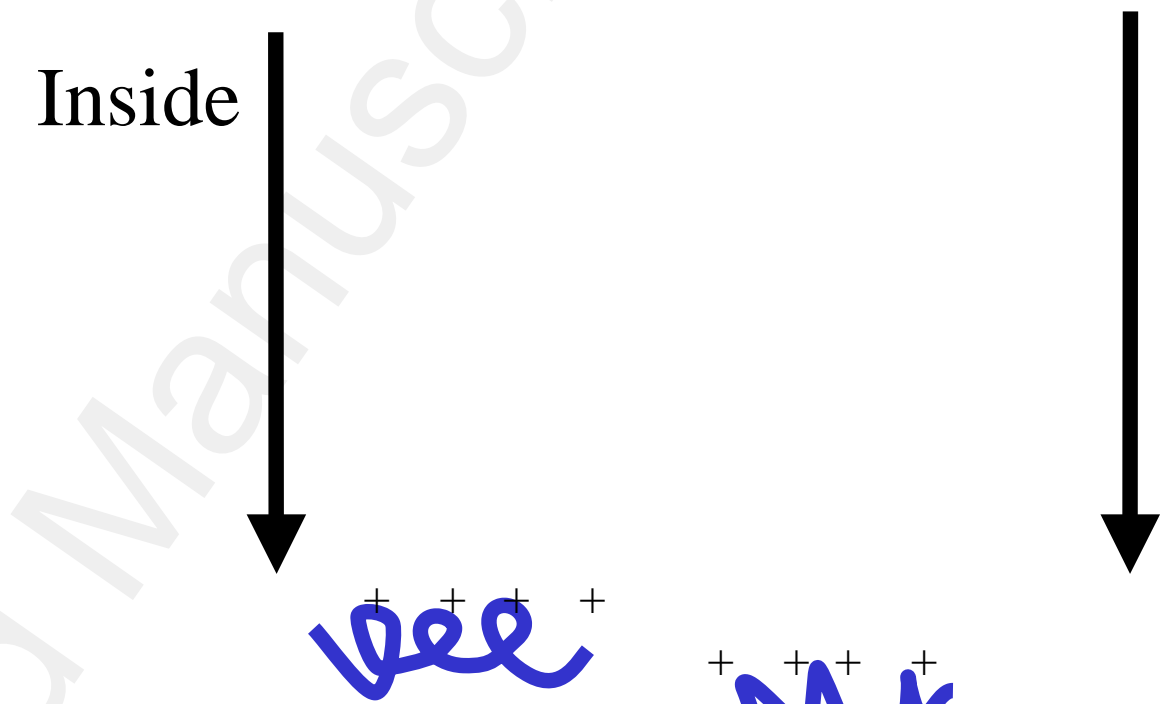

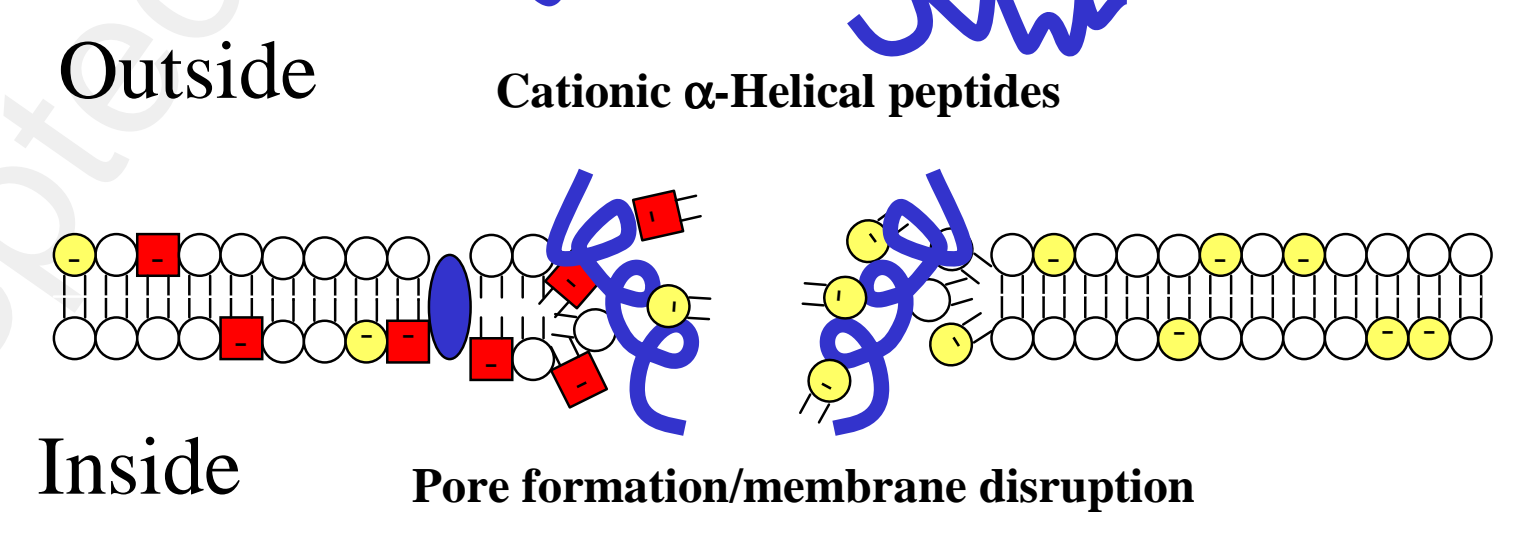

Outside

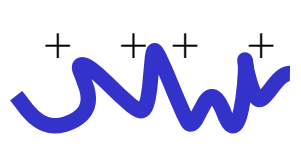




\section{Hecate-CG $\beta$}

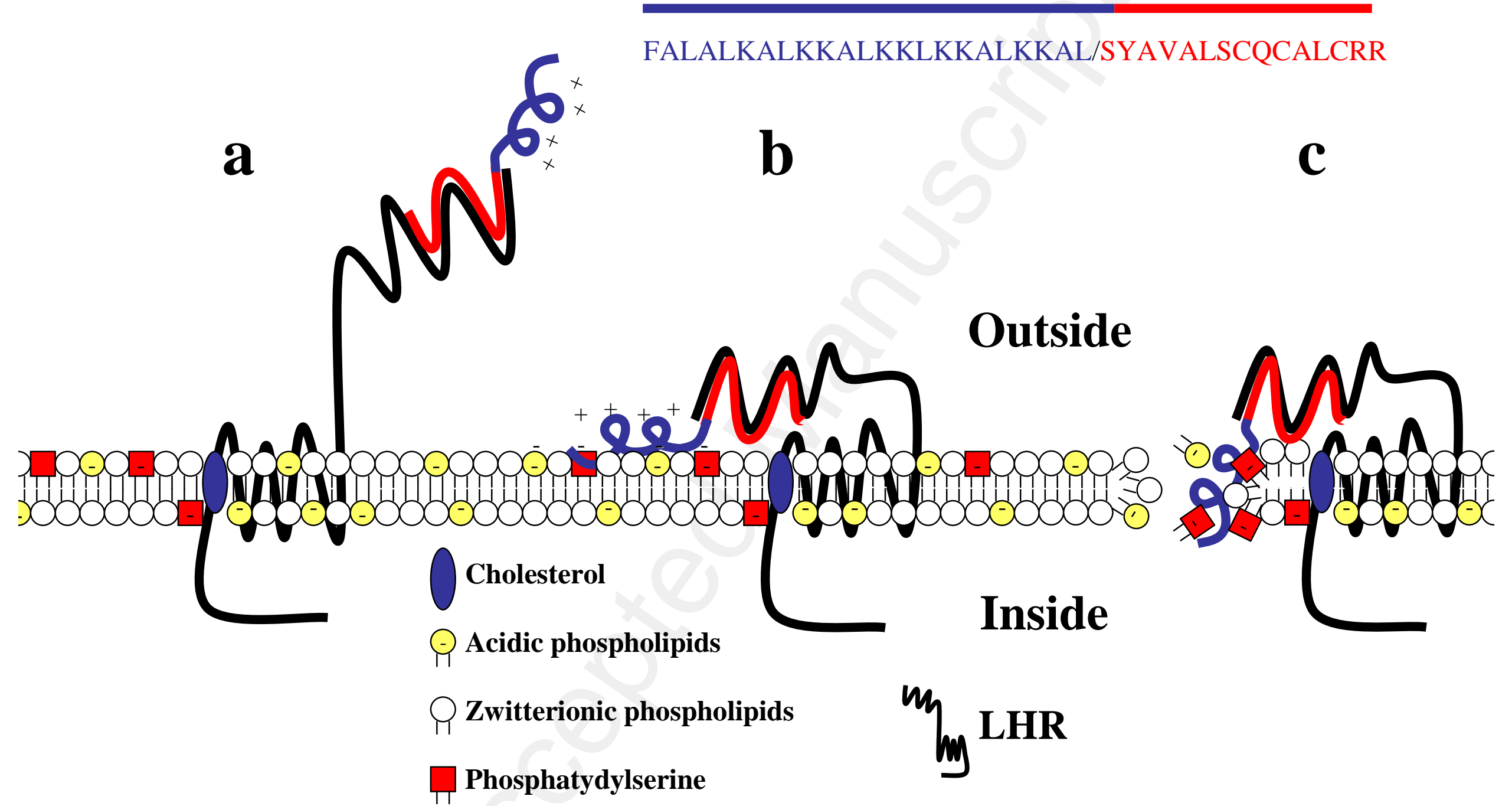

Fig. 2 


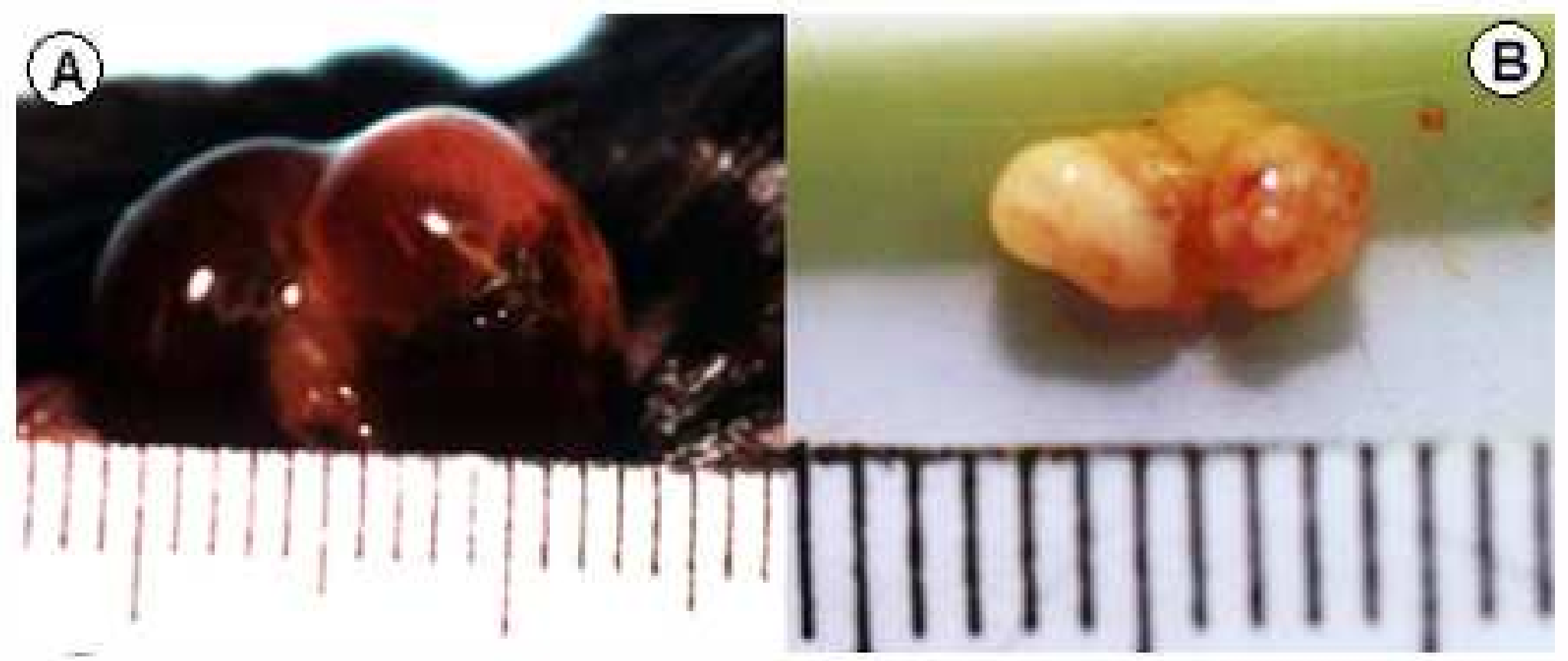

Fig. 3 

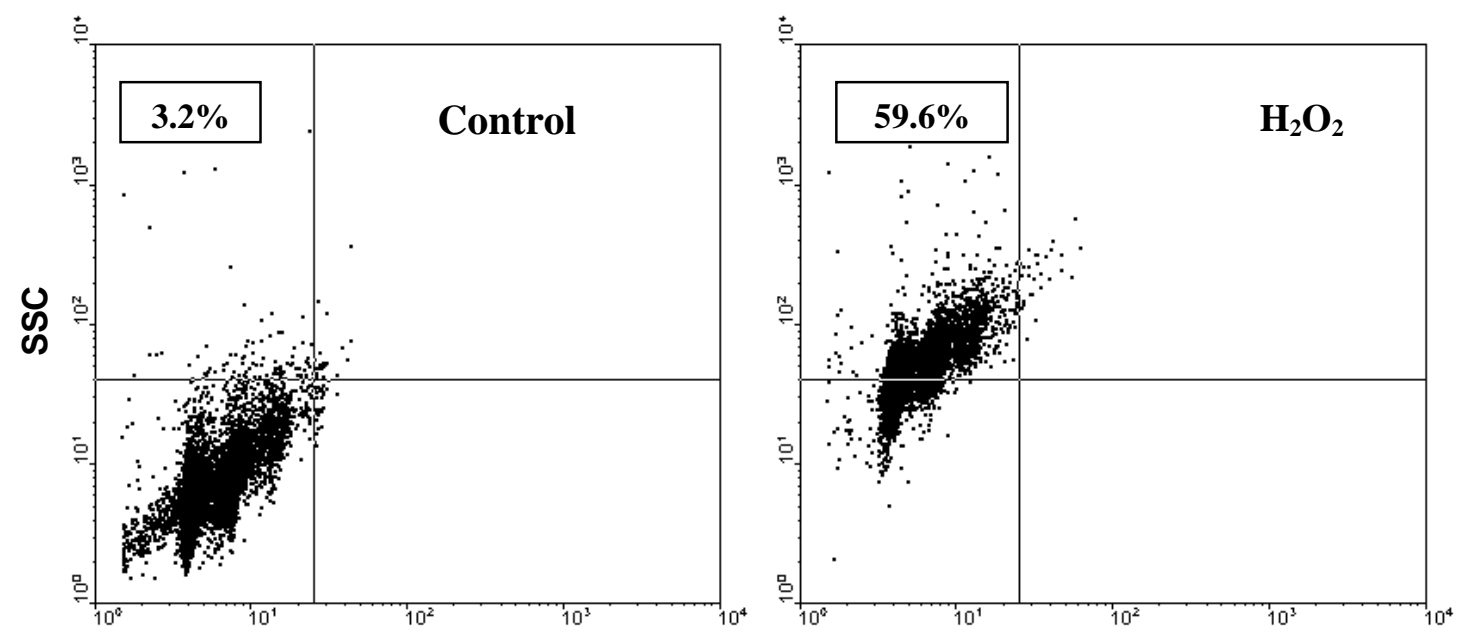

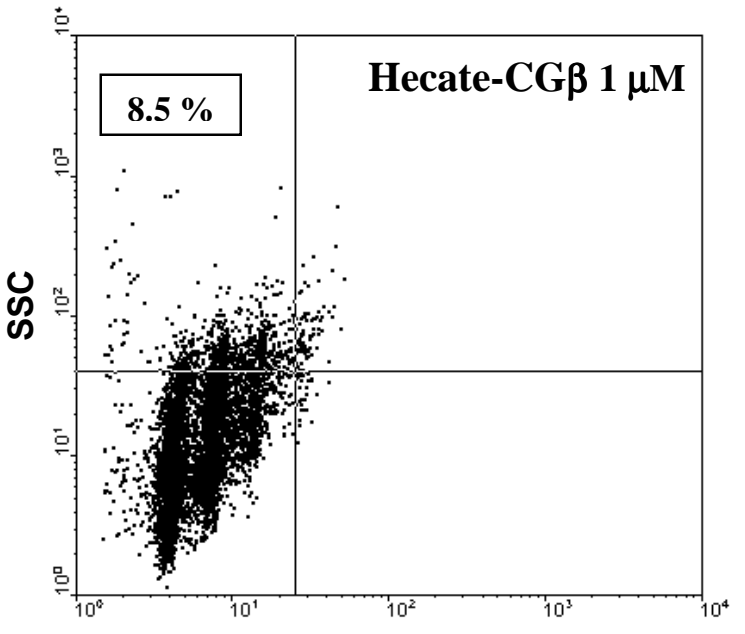

Fluorescent intensity

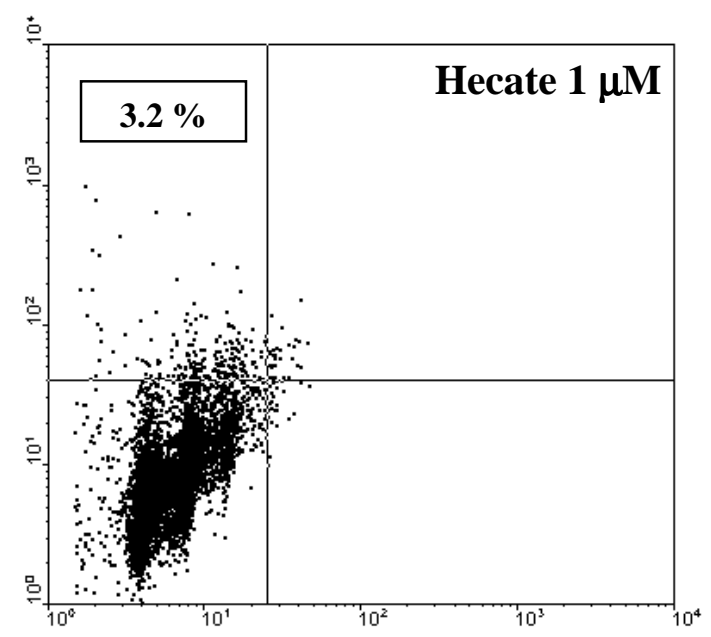

Fluorescent intensity

Fig. 4 
$\frac{7}{5}$

07
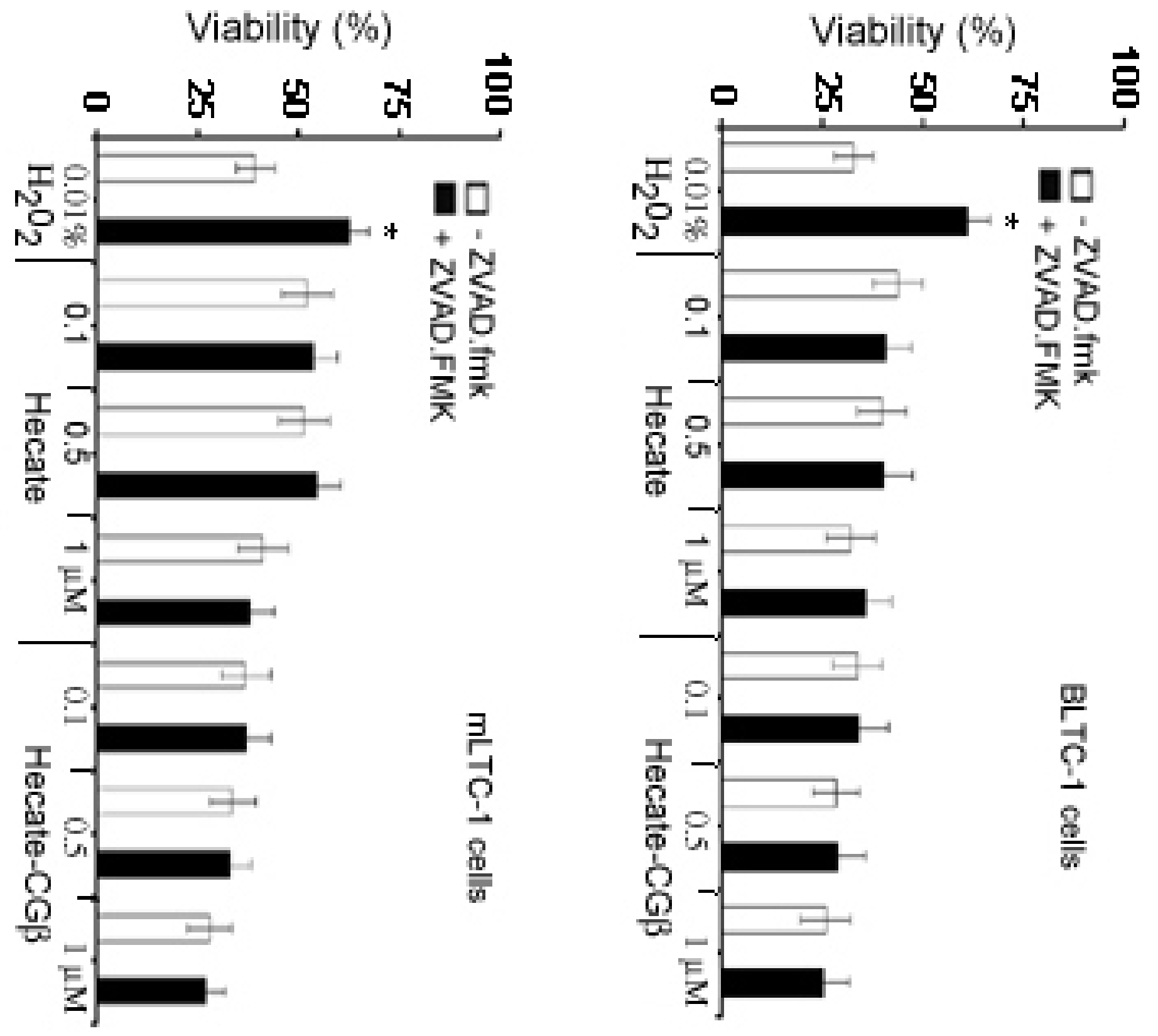